Tropical Journal of Pharmaceutical Research December 2016; 15 (12): 2719-2723

ISSN: $1596-5996$ (print); 1596-9827 (electronic)

(c) Pharmacotherapy Group, Faculty of Pharmacy, University of Benin, Benin City, 300001 Nigeria.

All rights reserved.

Available online at http://www.tjpr.org

Original Research Article

http://dx.doi.org/10.4314/tjpr.v15i12.26

\title{
Clinical efficacy of radiotherapy combined with sodium glycididazole in the treatment of recurrent oesophageal carcinoma
}

\author{
Yu-Yan Jiao ${ }^{1}$, Yu-Zhen Shen ${ }^{1}$, Yan Liu ${ }^{4}$, Hua Yan², Jing Wang ${ }^{3}$ and Jian-Zhe Li ${ }^{*}$ \\ ${ }^{1}$ Oncology Department (II), ${ }^{2}$ Pediatric Surgery Department, ${ }^{3}$ Cordiovascular Surgery Department, Taian City Central Hospital, \\ ${ }^{4}$ Dermatology Department, Taian Maternal and Child Health Care Hospital, Shandong, 271000, PR China \\ *For correspondence: Email: ljzlijz@163.com
}

Received: 22 June 2016

Revised accepted: 6 November 2016

\begin{abstract}
Purpose: To assess the clinical efficacy and side effects of radiotherapy combined with sodium glycididazole in the treatment of recurrent esophageal carcinoma.

Methods: Ninety patients with locally recurrent oesophageal carcinoma who were admitted to the Oncology Department at Taian City Central Hospital, Shandong, China, were randomly divided into a treatment group (treated with radiotherapy and sodium glycididazole) and a control group (treated with radiotherapy alone) in a randomized study. Short-term curative effects, median progression-free survival (PFS), and side effects were compared between the two groups.

Results: The cure rate in the treatment group was $86.70 \%$, whereas that in the control group was $51.10 \%(p<0.05)$. Median PFS in the treatment group was 9.9 months versus 5.3 months in the control group $(p<0.05)$. Side effects in both groups included alopecia, headache, nausea, vomiting and leucopaenia, at level one or two. In this regard, the difference between the two groups was statistically insignificant $(p>0.05)$.

Conclusion: Radiotherapy combined with sodium glycididazole shows a higher short-term curative effect in the treatment of recurrent oesophageal carcinoma than radiotherapy alone.
\end{abstract}

Keywords: Alopecia, Leucopaenia, Oesophageal carcinoma, Radiotherapy, Sodium glycididazole

Tropical Journal of Pharmaceutical Research is indexed by Science Citation Index (SciSearch), Scopus, International Pharmaceutical Abstract, Chemical Abstracts, Embase, Index Copernicus, EBSCO, African Index Medicus, JournalSeek, Journal Citation Reports/Science Edition, Directory of Open Access Journals (DOAJ), African Journal Online, Bioline International, Open-J-Gate and Pharmacy Abstracts

\section{INTRODUCTION}

Oesophageal carcinoma is a common gastrointestinal tract cancer and has high morbidity and mortality among malignant cancers $[1,2]$. Today, surgery is the major treatment method for oesophageal cancer [3,4]. However, the anatomical structure of the oesophagus causes skip metastasis in lymph nodes, making the elimination of lymph nodes during surgery more difficult. Thus, operative treatment alone does not control recurrence and metastasis of the disease and typically results in unsatisfactory long-term effects. Postoperative local recurrence and distant metastasis contribute to this failure of surgical treatment $[5,6]$.

More than $40 \%$ of patients are likely to have mediastinal lymph node metastasis or anastomotic recurrence after undergoing radical resection for oesophageal carcinoma, but it is often difficult for recurrent patients to undergo further surgery; thus, radiotherapy becomes the main treatment method [7]. However, radiotherapeutic effects are less than ideal. One of the main factors influencing radiotherapeutic efficacy is the insensitivity of $10-50 \%$ of hypoxic cells in a solid carcinoma to low linear 
energy transfer (LET) rays [8]. It has been shown clinically that many chemotherapy drugs can increase sensitivity; however, there are some adverse effects [9]. Sodium glycididazole, the only formally clinically used radiosensitiser with high efficacy and low toxicity, is a safe and effective radiosensitiser for hypoxic cells. In this study, we treated recurrent oesophageal cancer using radiotherapy combined with sodium glycididazole and obtained significant short-term effects.

\section{METHODS}

Ninety patients with confirmed recurrent oesophageal carcinoma, who were admitted to the Oncology Department at Taian City Central Hospital, Shandong, China from May 2013 to May 2015 were enrolled. Out of the number, there were 54 men and 36 women (age range, $39-79$ years, mean age, $56.7 \pm 2.3$ years). Karnofsky performance status scores of the patients were all > 70 points; the diameter of the tumour was from $1.8-6.1 \mathrm{~cm}$ and the average tumour volume was $88 \mathrm{~cm}^{2}$. The regional lymph nodes metastasis rate was $74.40 \%$, among which cervical lymph node metastasis accounted for $16.70 \%$, mediastinal lymph node metastasis for $25.60 \%$, cervical lymph node metastasis and mediastinal lymph node metastasis for $22.20 \%$, and anastomotic recurrence for $7.80 \%$. Patients were divided randomly into a treatment group (45 patients treated with radiotherapy and sodium glycididazole) and a control group (45 patients treated with radiotherapy alone).

This study was approved by the Medical Ethics Committee of Taian City Central Hospital (approval no. TCCH20151004JYY) and followed the guidelines of the Declaration of Helsinki [10]. All patients provided written informed consent.

\section{Radiotherapy plan}

Three-dimensional intensity modulated radiation therapy and 6-MV X-ray conventional segmentation treatment were used. Patients were given $1.8-2$ Gy each time, five times per week. The total radiation to the gross tumour volume was $60-66 \mathrm{~Gy}$, while that to the clinical target volume was 50-50.4 Gy.

Sodium glycididazole was provided by Shandong Green Pharmaceutical Co., Ltd., China. Sodium glycididazole for injection $\left(800 \mathrm{mg} / \mathrm{m}^{2}\right)$ was dissolved and diluted with $100 \mathrm{~mL}$ normal saline. Patients were given an intravenous infusion over 30 min. Patients then received conventional radiotherapy within $120 \mathrm{~min}$. This process was repeated three times per week until the end of radiotherapy.

Patients in the treatment group were treated with radiotherapy and sodium glycididazole; those in the control group were treated with radiotherapy alone.

\section{Evaluation of clinical and side effects}

In evaluating the response to radiotherapy, we used the Response Evaluation Criteria in Solid Tumours (World Health Organization) [11]. Complete remission (CR) referred to the disappearance of all target tumours. Partial remission (PR) meant that the size of target tumours was reduced by $30 \%$. Stable disease (SD) meant that the reduction in the size of the target tumours did not reach the standard for partial remission and the increase did not reach the standard for progression. Progressive disease (PD) meant that the size of the target tumours increased by $20 \%$ or there were new lesions. The formula for the overall effective rate was: overall effective rate $=$ (number of cases of complete remission + number of cases of partial remission) / total number of cases.

Adverse reactions were divided into four levels according to the National Cancer Institute Common Terminology Criteria for Adverse Events (ver. 3.0; NCl-CTC). Progression-free survival (PFS) was defined as the period from the beginning of radiotherapy to the death of patients.

\section{Statistical analysis}

Data were analysed using SPSS software (ver. 20.0, IBM, Armonk, NY, USA) and further assessed using $X^{2}$ tests. The data are expressed as percentages (\%). Comparison of data between the two groups was made using t-tests. The data are expressed as mean \pm standard deviation (SD). For survival analysis, we used Kaplan-Meier method. $P<0.05$ were taken to indicate statistical significance.

\section{RESULTS}

\section{Clinical effects}

Complete remission rates in the treatment and control groups were $26.70 \%$ and $17.80 \%$, respectively $\left(x^{2}=1.157, p>0.05\right)$. There was no significant difference between the groups. Overall response rates (CR + PR) were $88.90 \%$ and $51.10 \%$ respectively; there was a significant 
difference between groups $\left(x^{2}=5.03, p<0.05\right)$. Specific results are provided in Table 1.

\section{Analysis of survival rate}

The median PFS in the treatment group was 9.9 months $(95 \%$ confidence interval $(\mathrm{Cl})=5.13-$ 14.67 months), whereas that of the control group was 5.3 months $(95 \% \mathrm{Cl}=3.16-7.48$ months); the difference was statistically significant $(p<$ 0.05 ; Figure 1).

Side effects in both two groups included alopecia, headache, nausea, vomiting, and leucopaenia. The difference between the two groups was statistically insignificant $(p>0.05)$. Alopecia was at level two, and the other reactions were at level one (Table 2). There was no level three or four side effect. No serious organ damage occurred.

\section{DISCUSSION}

Anastomotic recurrence and/or mediastinal lymph node metastasis are the major reasons why patients who undergo oesophageal carcinoma operations die after $2-3$ years. By analysing 175 patients with recurrent oesophageal carcinoma who underwent threefield operations, Li et al [12] found that the lymphatic metastasis rate was $90.29 \%$, the anastomotic recurrence rate was $19.43 \%$, and the tumour area recurrence rate was $9.71 \%$. Among lymph node metastases, mediastinal lymph node metastasis at the superior mediastinum was the most commonly seen; abdominal lymph node metastasis is common with lower thoracic oesophageal carcinomas.

Zhu et al [13] analysed recurrence retrospectively in 98 cases of oesophageal carcinoma and found that lymph node metastasis ranked first, anastomotic recurrence second, and tumour area recurrence was the least common.

Table 1: Short-term effects of radiotherapy for recurrent oesophageal carcinoma $[N(\%)]$

\begin{tabular}{|c|c|c|c|c|c|}
\hline Group & CR & PR & SD & PD & ORR (\%) \\
\hline Treatment group $(N=45)$ & $12(26.70)$ & $28(62.20)$ & $3(6.70)$ & $2(4.40)$ & 88.90 \\
\hline Control group ( $N=45)$ & $8(17.80)$ & 15(33.30) & $14(31.10)$ & $8(17.80)$ & 51.10 \\
\hline
\end{tabular}

CR: complete remission; PR: partial remission; SD: stable disease; PD: progressive disease; ORR: overall response rate

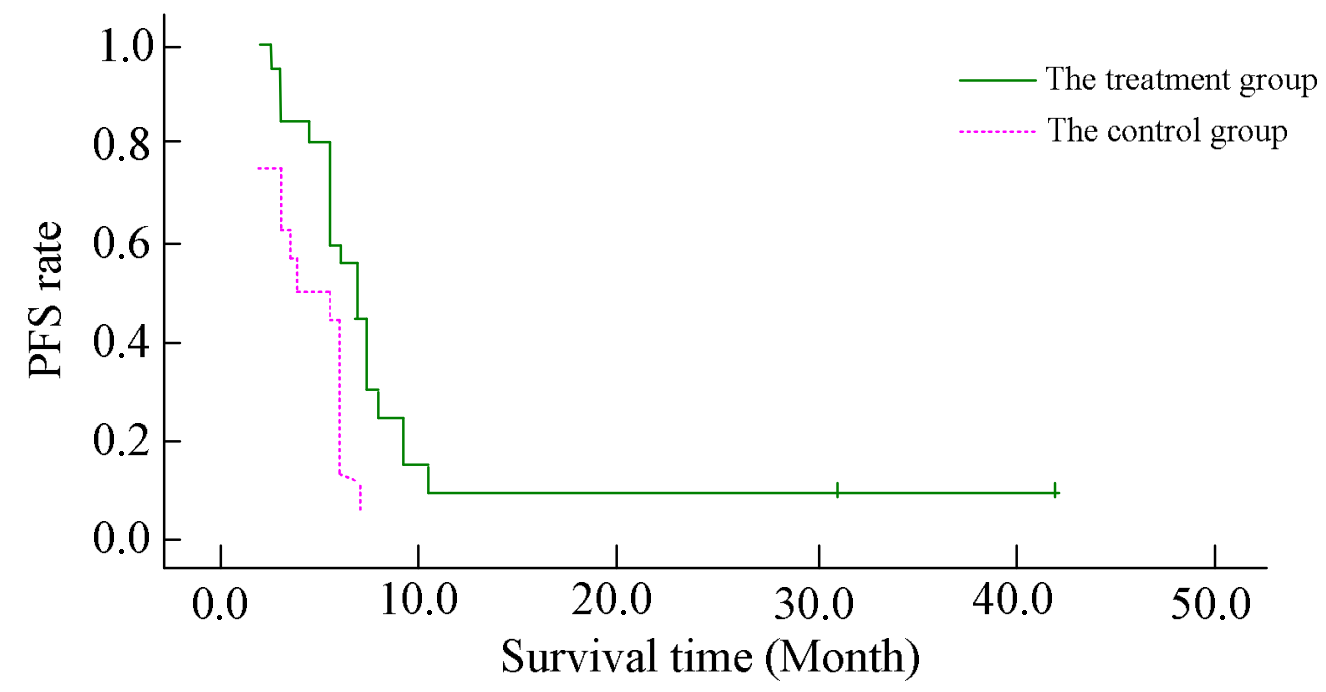

Figure 1: Analysis of progression-free survival (PFS) curves

Table 2: Comparison of toxic and side effects between the groups

\begin{tabular}{|c|c|c|c|c|c|c|c|c|}
\hline \multirow[b]{2}{*}{ Side effect } & \multicolumn{4}{|c|}{ Treatment group } & \multicolumn{4}{|c|}{ Control group } \\
\hline & $\begin{array}{c}\text { Level } \\
1\end{array}$ & Level 2 & Level 3 & $\begin{array}{c}\text { Level } \\
4\end{array}$ & $\begin{array}{c}\text { Level } \\
1\end{array}$ & Level 2 & Level 3 & Level 4 \\
\hline Alopecia & 0 & 45 & 0 & 0 & 0 & 45 & 0 & 0 \\
\hline Headache & 20 & 8 & 0 & 0 & 20 & 9 & 0 & 0 \\
\hline Nausea and vomiting & 14 & 8 & 0 & 0 & 16 & 9 & 0 & 0 \\
\hline Leucopaenia & 11 & 0 & 0 & 0 & 11 & 2 & 0 & 0 \\
\hline
\end{tabular}


Regarding treatment modalities for patients with recurrent oesophageal carcinoma, radiotherapy is the main method, but its clinical effects are unsatisfactory, which is considered to be related to hypoxia in cancer cells. Hypoxia, a common phenomenon in solid tumours, weakens radiotherapeutic efficacy by decreasing apoptosis [14]. Sodium glycididazole is a new nitroimidazole compound that increases the sensitivity to radiation. The drug has no anticancer effect per se; however, it can increase the sensitivity of hypoxic cells to radiotherapy and chemotherapy. The sensitivity mechanism of sodium glycididazole involves (1) strong damage and electron fixation and (2) suppression of DNA repair enzymes to tumour cells. Specifically, ionising radiation damages the tumour cells. The electrophilic group of sodium glycididazole captures electrons from damaged tumour target molecules. This promotes the generation of radical cations, accelerating the death of tumour cells. The suppression of DNA repair enzymes in tumour cells, especially polymerase B, strengthens the killing function in tumour cells by stopping DNA replication. This, in turn, decreases the oxygen dependence during the killing of tumour cells, suppressing potentially lethal and sub-lethal damage repair.

While sodium glycididazole can increase the sensitivity of tumour cells to radiotherapy and chemotherapy, it does not affect normal cells [15]. Additionally, it is characterised by high safety and efficacy because it does not accumulate in the patient's body. Previous clinical studies have shown that the drug can greatly increase the sensitivity of cells in head and neck neoplasms and oesophageal carcinoma, and it has good short-term effects [16-19].

A previous study compared the clinical effects of radiotherapy combined with sodium glycididazole and radiotherapy alone in the treatment of patients with brain metastases from breast carcinomas. The response rates in the treatment and control groups were $88.90 \%$ and $51.10 \%$, respectively; the difference was significant. The median PFSs of the two groups were 9.9 and 5.3 months, respectively; the difference was statistically significant.

Our results showed that treating patients with recurrent oesophageal carcinoma with radiotherapy and sodium glycididazole had positive effects, which were better than those in the control group. Moreover, we found no significant difference between the two groups in terms of side effects, such as alopecia, headache, nausea, vomiting, and bone marrow suppression $(p>0.05)$. All patients could tolerate the side effects; none of the patients discontinued treatment, suggesting that sodium glycididazole did not aggravate any adverse reaction.

\section{Limitations of the study}

The sample size in the study was small; thus, prospective clinical studies with larger sample sizes are required. Also, although there was an obvious difference in median PFS between the two groups, the research period was only 4 years. We were unable to show whether there was also a difference in longer-term PFS. Thus, the duration of follow-up needs to be extended in future studies.

\section{CONCLUSION}

Sodium glycididazole in combination with radiotherapy was more effective clinically in treating patients with local oesophageal carcinoma recurrence than radiotherapy alone. Moreover, the combined therapy did not aggravate side effects.

\section{DECLARATIONS}

\section{Acknowledgement}

The authors sincerely thank all who supported this work.

\section{Conflict of Interest}

No conflict of interest associated with this work.

\section{Contribution of Authors}

The authors declare that this work was done by the authors named in this article and all liabilities pertaining to claims relating to the content of this article will be borne by them.

\section{Open Access}

This is an Open Access article that uses a funding model which does not charge readers or their institutions for access and distributed under the terms of the Creative Commons Attribution License (http://creativecommons.org/licenses/by 14.0) and the Budapest Open Access Initiative (http://www.budapestopenaccessinitiative.org/rea d), which permit unrestricted use, distribution, and reproduction in any medium, provided the original work is properly credited. 


\section{REFERENCES}

1. Shi J, Peng Y, Ding SR, Wang LM, Wang R, Gao YG. Influential factors of esophageal cancer in residents of Hebei province: a case-control study. Chin J Public Health 2012; 28(4): 454-457.

2. Sugihara $H$, Ishimoto $T$, Miyake $K$, Izumi $D$, Baba $Y$, Yoshida N, Watanabe M, Baba H. Noncoding RNA expression aberration is associated with cancer progression and is a potential biomarker in esophageal squamous cell carcinoma. Int J Mol Sci 2015; 16(11): 27824-27834.

3. Tian XJ, Zhang HX. Clinical epidemiological analysis of 1256 cases of esophagus cancer detected by endoscope. Chin Pract Med 2012; 7(23): 91-92.

4. Li Z, Wang Y, Ma J, He J, Zhou J, He F, Skog S. Transient increase in serum thymidine kinase 1 within one week after surgery of patients with carcinoma. Anticancer Res 2010; 30(4): 1295-1299.

5. Lu J, Tao H, Song D, Chen C. Recurrence risk model for esophageal cancer after radical surgery. Chin $J$ Cancer Res 2013; 25(5): 549-555.

6. Oppedijk V, van der Gaast $A$, van Lanschot $J J$, van Hagen $P$, van Os $R$, van Rij CM, van der Sangen MJ, Beukema JC, Rütten $\mathrm{H}$, Spruit $\mathrm{PH}$, et al. Patterns of recurrence after surgery alone versus preoperative chemoradiotherapy and surgery in the CROSS trials. J Clin Oncol 2014; 32(5): 385-391.

7. Li DR Chen ZJ, Lin ZH, Hong H. Significance of radiation treatment for neck and mediastinal lymph node metastasis after surgery for esophagus cancer. Chin $\mathrm{J}$ Clin Oncol 1997; 24(10): 753-755.

8. Chen J, Zhou ZR. Research on evaluation of tumor radiotherapy effect in anoxic conditions. Chin J Radiat Oncol 2013; 21(3): 275-277.

9. Wang FY, Sun J, Bao YH, Zhang SW, Xu GZ. Role of $C M N a$ in enhancing radiosensitivity of esophagus carcinoma. Chin J Clin Med 2001; 8(4): 369-371.

10. Declaration of Helsinki. The 59th World Medical Conference, 2008.
11. Yang XN, Wu YL. RECIST-New guidelines to evaluate the response to treatment in solid tumors. J EvidenceBased Med 2004; 4(2): 85-90.

12. Li JC, Xu ZC, Pan JJ, Wang LH, Chen MF, Yang Y. Comparison of local recurrence patterns of esophageal carcinoma after surgery with and without postoperative radiotherapy. Chin J Oncol Prev and Treat 2012; 4(4): 331-335.

13. Zhu QW, Cai J, Huang CH, Wan ZL. Recurrence of postoperative esophageal cancer and design of radiotherapy target area in 98 cases. Chongqing Med $\mathrm{J}$ 2013; 42(14): 1580-1582.

14. Liu WJ, Sun L, Yu JM, Li MH, Hu M, Shi F, Lv WT, Zhang $H Q$. Pattern of recurrence following complete resection of thoracic esophageal squamous cell carcinoma and significance of adjuvant therapy. Chin J Clin Oncol 2010; 37(23): 1358-1361.

15. Fu LQ, Guo JH, Gao HZ, Sun CC, Liang YQ, Wu DZ. Research on stage I clinical pharmacokinetics of tumor radiosensitizer sodium glycididazole. Chin J Clin Pharmacol 2000; 16(3): 187-190.

16. Li MY, Liu JQ, Chen DP, Qi B, Liang YY, Yin WJ. Glycididazole sodium combined with radiochemotherapy for locally advanced nasopharyngeal carcinoma. Asian Pac J Cancer Prev 2014; 15(6): 2641-2646.

17. Zeng $Y C, W u R, X u Z G$, Zhang $X Y$, Fan GL, Wu $L N$, Wang $Y M$, Hao $S H$, Zheng $W$, Chen $X D$, et al. Safety and radiation-enhancing effect of sodium glycididazole in locoregionally advanced laryngeal cancers previously treated with platinum-containing chemotherapy regimens: A preliminary report. Cancer Radiother 2010; 14(1): 59-64.

18. Cai L, Liu MZ, Gu MF, Liu H, Chen EC, Hu YH, Lin $H X$, Wang HY, Huang Y, Li QQ, et al. Phase I study of CM$\mathrm{Na}$ combined with concurrent radiochemotherapy for advanced esophageal carcinoma. Cancer 2005; 24(5): 582-586.

19. Lu H, Zhao D, Yu DH, Ma J, Zhang BY, Song W. Clinical observation of sodium glycididazole combined with concurrent radiochemotherapy for locally advanced esophageal cancer. Chin Clin Oncol 2014; 19(10): 921924. 